\title{
Article
}

\section{A Didactic Model of Sustainability Commitment}

\author{
Johan Öhman ${ }^{1, *}$ and Louise Sund ${ }^{1,2} \mathbb{D}$ \\ 1 School of Humanities, Education and Social Sciences, Örebro University, 70182 Örebro, Sweden; \\ louise.sund@mdh.se \\ 2 School of Education, Culture and Communication, Mälardalen University, 72220 Västerås, Sweden \\ * Correspondence: johan.ohman@oru.se
}

check for

updates

Citation: Öhman, J.; Sund, L. A Didactic Model of Sustainability Commitment. Sustainability 2021, 13, 3083. https://doi.org/10.3390/ su13063083

Academic Editor: David González-Gómez

Received: 3 December 2020

Accepted: 8 March 2021

Published: 11 March 2021

Publisher's Note: MDPI stays neutral with regard to jurisdictional claims in published maps and institutional affiliations.

Copyright: (C) 2021 by the authors. Licensee MDPI, Basel, Switzerland. This article is an open access article distributed under the terms and conditions of the Creative Commons Attribution (CC BY) license (https:// creativecommons.org/licenses/by/ $4.0 /)$.

\begin{abstract}
This article proposes a model that describes and frames sustainability commitment. The model is based on didactic theory and pragmatic philosophy and is informed by several empirical studies on environmental and sustainability education (ESE) practice. The intention is for the model to serve as a critical perspective on ESE practices in secondary and upper secondary schools, and to offer a framework for the development of future practice with emphasis on teachers' choices of content and teaching methods. The model suggests that a sound commitment is situated in the intersection of the intellectual, emotional, and practical aspects of sustainability. It is argued that: The intellectual aspect is essential for giving the commitment scientific rigor and a critical stance; emotions are vital for students to become dedicated; and skills to carry out appropriate actions for change is necessary for playing an active role in providing a sustainable transformation of society.
\end{abstract}

Keywords: education; didactics; teaching; learning; pragmatism; sustainability commitment

\section{Introduction}

From the Agenda 21 plan of action to the adoption of the 2030 Agenda for Sustainable Development there has been an international policy aspiration to reorient and implement education towards sustainable development. The broader Sustainable Development Goal (SDG) 4 (quality education), and specifically SDG 4.7: “By 2030, ensure that all learners acquire the knowledge and skills needed to promote sustainable development, including, among others, through Education for Sustainable Development and sustainable lifestyles, human rights, gender equality, promotion of a culture of peace and nonviolence, global citizenship and appreciation of cultural diversity and of culture's contribution to sustainable development" [1] (p. 8), give added impetus to the sustainability themes that have emerged in various educational policy papers published at the national level, particularly in Western Europe/the global North.

The inclusion of sustainability themes in educational policy also raises questions about educational and teaching goals and choices of content, forms, and methods. In recent decades schools all over the world have been addressing this challenge [2]. Depending on country, environmental and sustainability education (ESE) can be a subject, an aspect of civics or of citizenship education, or a broader cross-curricular theme. Exploring the relationship between education and sustainable development, Vare and Scott [3] have emphasized the importance of seeing sustainable development as a social learning process (as opposed to a set of pre-determined behaviors), which concerns the building of capacity to think critically about and explore the dilemmas and contradictions inherent in sustainable transformation. Scott [4] argues that building this capacity is a central aim of schools:

In terms of sustainability, then, the purpose of schools might be seen as stimulating young people's development of awareness and interest in relation to living sustainably with the hope (but not certainty) that this will give rise to social participation that can contribute, for example, to the goals of greater social justice and human well-being, and the bolstering of the resilience of ecological systems (p. 413). 
In this article, we refer to Scott's suggestion of the purpose of schools as supporting the creation of students' sustainability commitment. By sustainability commitment we mean a desire and ability to contribute to a sustainable transformation of our world. The question is, what is the content and structure of a commitment to sustainable development? What can be considered to be an ethically and politically sound commitment? How might teachers support the development of such a commitment? The purpose of this article is to suggest a model that describes and frames sustainability commitment and tentatively answers these questions. The intention is for the model to provide critical perspective on ESE practices in secondary and upper secondary schools that will serve as a framework for the development of future practice with emphasis on teachers' choices of content and methods when teaching on sustainability issues.

The model is based on Nordic and German didactic theory [5] and John Dewey's pragmatic philosophy [6-11] and is the result of years of empirical study conducted by the research group SMED (Studies of Meaning-making in Educational Discourses) (for an overview of this research see $[12,13])$. In this article, we use empirical examples collected from a recent research project called "Teaching global equity and justice issues through a critical lens" (Swedish Research Council, project number 2017-03468) to illustrate the different aspects of the model and the related teacher actions.

\section{Background: Key Competencies and Action Competence}

We begin by reviewing earlier significant research and different attempts to define the content and structure of sustainability awareness and interest. The focus is on two specific areas of research: key competencies and action competence.

In numerous articles and reports, the strategy to address the sustainability challenge has been translated into interconnecting and associated combinations of key competencies for sustainable development [14-17]. Key competencies are described as critical reference points for developing curricula and courses [17] and "the ambitious knowledge and skill profile of students expected to be future 'problem solvers,' 'change agents,' and 'transition managers'" [16] (p. 204). At the policy level, and based on (among other references) the above research, UNESCO has identified eight cross-cutting key competencies for sustainability that are of particular importance for thinking and acting in favor of and advancing sustainable development: systems thinking competency, anticipatory competency, normative competency, strategic competency, collaboration competency, critical thinking competency, self-awareness competency and integrated problem-solving competency [1] (p. 10). Rieckmann [18] also provides an overview of some of the competences that are needed to deal with sustainability challenges. Key competencies are essential for individuals to become "sustainability citizens" [19] and are what active and critical sustainability citizens will need in order to deal with complexity and uncertainty, design strategies to address these aspects and, perhaps most importantly, change their own lifestyles to reflect a more sustainable and just society $[1,20]$ and open the door to sustainable development. The key competencies are also useful when constructing educational programs on sustainable development (a broader end) and describing what students will need to live sustainably (output).

However, there is also substantial critique towards key competencies as an educational concept (for an overview of this critique see [21]). Willbergh [21] argues that that "the term loses its meaning when implemented into practice and simply designates performance and skills" (p. 336). Key competencies are based on the idea that we can predict what is needed in the future. However, assessing competencies of the future is very difficult and there is a problem with competence as an educational concept as it assumes that what is judged to be keys to success today will be context-independent and stable [21]. Furthermore, the problem is that there is still no agreement as to what key competences in general really are [14], which is important when it comes to identifying context-specific key competencies for sustainability. There is a lack of theoretical anchoring and empirical evidence to show which competencies are crucial and sufficient for living sustainably, or that enable students 
to take part in sustainability problem-solving. Furthermore, these core competencies have not been the main focus of formal education [18] (p. 45). Although the Global Action Program (GAP) aims to expand and mainstream Education for Sustainable Development (ESD) at all levels and in all areas of education, we know very little about competencies that are essential for sustainability in formal education and how they are connected to teaching-learning relationships. Key competencies also focus on a specific goal or learning outcomes in the form of capacities and skills [16,18], rather than on the learning process and the educational content. Another question concerns the implementation of competence orientation and how to incorporate it into the teaching practice; something that is hampered by didactic challenges such as how to move the focus from the "what competencies" question to that of "how can concrete competencies be fostered?" [22] (p. 9). Thus, although the key competence concept has been valuable at the program level, it gives teachers little guidance when it comes to organizing classroom practice.

More oriented towards teaching and learning is the concept of action competence [23,24]. As noted by the Danish researchers who coined the phrase "action competence" as an educational concept, there is an important difference between viewing "competence" as a countable word with plural forms (outcomes that include certain core competencies) and "competence" as an educational philosophical ideal associated with "being able, and willing, to be a qualified participant" [23] (p. 473). An action competence approach is skeptical of educational paradigms in environmental and sustainability education that regard the educational task as a question of behavior modification: "Through the spectacles of action competence, you may look for and ask for and measure different (key) competencies, but action competence will not be one of them. Action competence will be the lens that makes some types of knowledge, skills, qualifications, competencies, abilities, and action readiness more educationally important and valuable than others" [23] (p. 67). Some researchers $[4,23,24]$ argue that there is a need for a form of teaching that focuses on the development of critical thinking skills, dialogue and debate (naturally integrated into the focus on content) and on how students "acquire the courage, commitment and desire to get involved in the social interests concerning these subjects (naturally based on understanding and insight)" [23] (p. 472).

In keeping with Jensen and Schnack [23], we relate commitment to students' motivation and assertiveness, both of which are crucial for turning knowledge about sustainability problems/issues into action. A sustainable commitment is situated and personal at the same time, in that it needs to be relational and informed by a social context. It is, therefore, an ongoing commitment over time. Compared to the key competencies for sustainability, a commitment speaks back to you, in the sense that you want to do something. However, in a sound commitment this desire to act must, as Jensen and Schnack [23] put it, be "based on understanding and insight" (p. 472). To be more precise, we argue that it needs to be based on scientific knowledge and ethical and political insights.

Action competence is now receiving more scholarly attention, particularly in the context of interpreting the concept as a latent competence or as an overarching educational approach. To redefine action competence, Sass, Boeve-de Pauw, Olsson, Gericke, De Maeyer and Van Petegem [25] break down action competence into "the willingness, commitment, knowledge, skills and confidence to engage in finding solutions to controversial problems or issues" (p. 6). The authors offer an overview and current usage of the concept of action competence in sustainable development research and undertake a critical discussion of how the term can be seen as the "competence of people to engage in solving sustainability issues" (p. 1). We see this attempt as an interesting way of theoretically conceptualizing competence and believe that by empirically engaging the theoretical perspective with classroom practice and building a model on didactic theory we can add another layer to the knowledge/aspect of approaching ESE from a competence point of view, i.e., in order to incorporate sustainability commitment into teaching practice, we need to add an idea about the content, the different components and aspects of such a commitment, and a theory about how students make this content their own. To develop a model for this, we 
turn to John Dewey's educative view of experience and Klafki's didactic theory on how the content "becomes something" in the educational situation.

\section{Research Process}

The study relies on two theoretical perspectives-didactics and pragmatism-both providing complex and comprehensive understandings of teaching practice and students' learning. The suggested didactic model of sustainability commitment has been developed through abduction or retroduction [26,27], where the theoretical explanations have been tested against empirical data material in a back and forth process. According to Charles Sanders Peirce [27], the term abduction originates from a misunderstanding and a mistranslation and should instead be called retroduction (see CP 1.65). Building on and interpreting Peirce's work, Glynos and Howarth [28] explain that retroductive reasoning generates a new standard of explanation and captures the process by which a researcher adopts hypotheses and constructs theories. Retroductive reasoning starts with studying the facts (observations derived from experience) and devising a plausible conjecture or hypothesis (theory) to explain them. As Peirce [27] puts it: "abduction, although it is very little hampered by logical rules, nevertheless is logical inference, asserting its conclusion only problematically or conjecturally, it is true, but nevertheless having a perfectly definite logical form" (CP 5.188, p. 3794). Using the retroductive method, we seek to build theory from practice, or as described by Walsh [29], "theorizing from and with praxis" (p. 84), to contribute a praxis point of view to empirically engage the theoretical perspective with classroom practice.

\section{Theoretical Perspectives}

In the following, we present the two theoretical perspectives that have guided the retroductive process: Nordic and German didactic theory (Didaktik) and John Dewey's pragmatic theory on experience. We outline the basic ideas of these perspectives that have influenced the development of the model of sustainability commitment.

\subsection{Didaktik: The Question of Educational Content}

Nordic and German didactic theory encompasses general ideas about the role and purpose of schools in society and that which directly affects the teaching process. One way of structuring an understanding of Didaktik is to start from the three main questions in education: why? - the motives of education, what?- the content of education and how? - the methods used in education [30].

At a societal level, the why question addresses the purpose of schools and the visions of an ideal society. It also considers the role of the school in preparing students for life in a democracy/democratic processes. The what question concerns the standards on which to base the choice of content and the grounds on which a certain material is chosen. Even in a fixed and compulsory curriculum, teachers have a significant amount of freedom to decide which content to use. The question therefore is, which central and important content should be selected and presented in each case in the frames and circumstances set by society and the school? The what question also concerns how to structure, organize, and present the content. The how question deals with the choice of work methods and approaches. It also emphasizes how students can achieve the goals that have been set for the education, which includes an understanding of the learning process that takes place when teachers and students mutually enact the content, and how the role of the teacher is perceived.

In the Nordic and German Didaktik tradition, the what question about the educational content is particularly important. As we see it, the strength of this tradition is that it problematizes how teaching can unlock the educational potential of a given content and allow students to turn matter into meaning [31,32]. In this tradition, the curriculum outlines a certain content for the teaching, but is not seen as something that explicitly direct a teacher's work. Rather, the curriculum is viewed as something "that can only become educative 
when interpreted and given life by teachers" [33] (p. 177). According to Hudson [33], this tradition emphasizes that teachers can exercise substantial professional autonomy and have the freedom to teach without the control of a curriculum. Thus, didactic considerations include what a teacher needs to respond to and how to create the conditions required for students' learning. To select educational content, the renowned German didactic theorist Wolfgang Klafki suggests five basic questions of "didactic analysis" [5,34,35]. These mutually dependent questions represent the basis for selecting and working with the content of a teacher's daily lessons. The first question focuses on exemplarity: "What wider or general sense or reality does this content exemplify and open up to the learner?" The second question is aimed at the meaning and contemporary significance of the content for the students in the class. With the third question, Klafki asks about the future meaning of the content. After having pedagogically placed the content in the context of its educational potential regarding the exemplary, present and future relevance for the student (questions 1-3), Klafki turns to the fourth question about the wider context of this content and how it can be broken down. Finally, the fifth question focuses on accessibility and how the content can become interesting and approachable: "What is the body of knowledge which must be retained ("minimum knowledge") if the content determined by these questions is to be considered "acquired", as a "vital", "working" human possession?" [34].

A crucial aspect of content is the difference that Klafki makes between matter and meaning, which means the content as such (Inhalt) and its educational substance (Gehalt). Hopmann [31] emphasizes that this difference is not simply one of facts and beliefs: "they are what they are by the substance meeting the teacher and the student while meeting the content" (p. 116). He continues by saying that "meaning is what emerges when the content is enacted in a classroom based on the methodological decisions of a teacher, i.e., his or her pedagogical freedom" (p. 117). What Klafki's didactic perspective contributes is how the content becomes something in the educational situation and when students actually learn it. This is close to pragmatists' claim that the meaning of concepts must be brought out or "cashed out" in experiential terms and consequences (see below). William James [36] (Lecture 2) used cash-value metaphorically to describe that a meaningful concept must be related to empirical observations: "You must bring out of each word its practical cash-value, set it at work within the stream of your experience." This means that a teacher selecting the content must consider and critically analyze the meanings that students create and how it might help them to achieve "the abilities of self-determination, co-determination and solidarity" [34] (p. 14). Klafki understands knowledge as situated, contextual and normative and his development of a critical perspective is infused with a focus on reacting to social conditions and processes that work against a more just society.

Klafki's ideas about how content can become accessible to and approachable for students is of central importance for the suggested sustainability commitment model. We would also like to add how the content can become actionable, defined as having practical value for the students to act on [37]. We understand the concept of commitment as being in line with the didactic concept of Bildung and the way in which teaching "opens up a world for the student, thus opening the student for the world" [31] (p. 115). In contrast to a key competence approach which is built on anticipated skills for the future, the Bildung concept focuses on engaging with students to understand what matters to them and their future and ethical choices. Willbergh [21] argues that the educational idea of Bildung is to support student independence, so that "the younger generations themselves will be able to decide in the future what they consider to be useful, successful and last but not least, ethical" (p. 341).

To unfold what it means in terms of students' learning to open up for the world and take responsibility for the future, we turn to John Dewey's pragmatic philosophy and especially his concept of experience. 


\subsection{Pragmatism: Experience and Relationality}

In developing our didactic model of sustainability commitment, Dewey's notion of experience as indispensable to all learning is essential [11]. It is through the process of experience that we learn to (practically, emotionally and intellectually) navigate our course as individuals and as a pluralistic society.

Dewey [11] describes experience as an interplay that involves the interaction between objective conditions (equipment, books, materials including "what is done by the educator and the way in which it is done", p. 45) and the student's internal conditions (previous experiences manifested as acquired habits). It is by acting and undergoing the consequences of our actions in a specific situation that we develop an understanding or grasp the meaning of the situation, or to use Dewey's words, "to see it in its relations to other things: to note how it operates or functions, what consequences follow from it, what causes it can be put to" [9] (p. 225). Thus, knowledge is intimately connected with action, or the happening of experienced things. As Dewey [7] explains: "to discover the conditions and consequences of [experience] happening / ... / can take place only by modifying the given qualities in such ways that relations become manifest" (p. 84). We can therefore understand these manifested relations as practical, emotional, and intellectual aspects of our habits.

According to Dewey [11], every (genuine) experience modifies us, and in a sense, "the world". When individuals live through a learning experience, they are not only actors of the world, but are also receptive to and undergo the world, and thus need to be able to question and change previous habits of acting, feeling and thinking: "For 'taking in' in any vital experience is something more than placing something on the top of consciousness over what was previously known. It involves reconstruction which may be painful" [10] (p. 41).

This experiential understanding of learning means that student learning is not an invisible mental process that is carried in the head, but something that is in the practices or situations in which the students are involved and respond to through action. For the teacher, choosing the situations in which this interaction takes place and considering the whole learning environment to adapt to the needs of the student group is an important task. For Dewey [11], this means that the teacher is the one with "the greater maturity of experience" and who therefore needs to organize and evaluate the direction in which the students' experiences are heading ("what it moves toward and into") (p. 38).

From Dewey's pragmatic perspective, a complete and entire learning process (experience) consists of a series of overlapping elements or aspects, where disciplinary knowledge is not sufficient to reach a situation that involves concern for someone or something: "It is not possible to divide in a vital experience the practical, emotional, and intellectual from one another and to set the properties of one over against the characteristics of the others. The emotional phase binds parts together into a single whole; 'intellectual' simply names the fact that the experience has meaning; 'practical' indicates that the organism is interacting with events and objects which surround it." [10] (p. 55, our emphasis).

According to Dewey, an experience has a unity that is constituted by a quality that pervades the entire experience. The existence of unity is not strictly emotional, practical, or intellectual, as these distinctions are made in hindsight, by way of reflection. Furthermore, the experience is not the sum of these different characters: "They are phases, emotionally and practically distinguished, of a developing underlying quality; they are its moving variations, not separate and independent" [10] (p. 37).

Following Dewey, and to sum up, the intellectual, emotional, and practical aspects represent different phases or aspects of human nature. The intellectual aspect represents rationality, understanding, reason, responsibility etc., the emotional aspect represents sensibility, emotion, spontaneity, devotion etc., and the practical aspect indicates "our dealings with things" [10] (p. 193), events and objects that surround us. There is no intrinsic (psychological) division between these aspects of experience, but for didactic reasons it is often fruitful to make an analytical distinction between the practical, emotional, 
and intellectual-and it is this that constitutes the core of our model for sustainability commitment.

\section{Empirical Input}

The empirical input for the development of the suggested didactic model is based on several projects and studies of ESE practices in secondary schools (See for example: [38-44].). In this article, we specifically use empirical examples collected from a recent research project called "Teaching global equity and justice issues through a critical lens" (Swedish Research Council, project number 2017-03468) to illustrate the model and make it more comprehensible and tangible. This project examined how Swedish upper secondary school teachers take up the most pressing sustainability problems facing the world today in their teaching practices, such as migration, climate change, and social and economic inequalities. The empirical examples are gathered from the classroom observations and interviews with teachers and students. They allow us to illustrate what the different aspects might look like in educational practice and how teachers guide students' inquiries in relation to the different aspects of a sustainability commitment. It is important to stress that the empirical data does not say anything about a sustainability commitment per se, but focuses on teaching and learning processes. However, the data exemplifies how commitment may emerge and how teachers can support this in educational practice. Since data is used only to illustrate our argument, we leave out the full details of the research design of the project. Nor do we detail the larger data set which includes transcripts of the interactions between teachers and their student groups.

\section{A Didactic Model of Sustainability Commitment}

Based on the empirical studies, didactic theory and Dewey's ideas about experience and learning outlined above, we argue that a commitment should consist of three interrelated aspects: an intellectual aspect, an emotional aspect, and a practical aspect. For students to develop a sound sustainability commitment, it is important that they are presented with a variety of learning experiences that will help them to:

- $\quad$ acquire knowledge about sustainability issues and relate (position/locate themselves) to that knowledge (the intellectual aspect),

- articulate their emotional response and emotionally relate to sustainability issues (their ethical standards and beliefs) (the emotional aspect),

- develop their ability, motivation and desire to play an active role in finding democratic solutions to sustainability issues (the practical aspect).

The basic components and structure of this sustainability commitment model are presented in Figure 1. In the following, we describe the different aspects of the model and the related didactic principles in more detail. Although for reasons of clarity we describe the aspects separately, it is important to underline that it is the reciprocal relationship between these aspects that forms the conditions for a sustainability commitment based on scientific knowledge and ethical and political insights. In this way, we could say that a sound sustainability commitment lies at the intersection of the intellectual, emotional, and practical.

\subsection{The Intellectual Aspect}

The intellectual aspect of sustainability commitment is in two parts: (a) students rational knowledge about sustainability issues and (b) students' own relationship to this knowledge in terms of their epistemic, ethical, and political position or location.

Every school subject has content knowledge or disciplinary knowledge that students are expected to learn. The process of selecting and introducing subject content is a fundamental aspect of teaching sustainability issues. It is reasonable to stress that some of this knowledge involves understanding nature and the biosphere (i.e., ecosystem services, biodiversity, and the carbon cycle). Essential knowledge arguably also concerns 
the relationships between humanity and the biosphere (i.e., poverty reduction, economic development, and climate change).

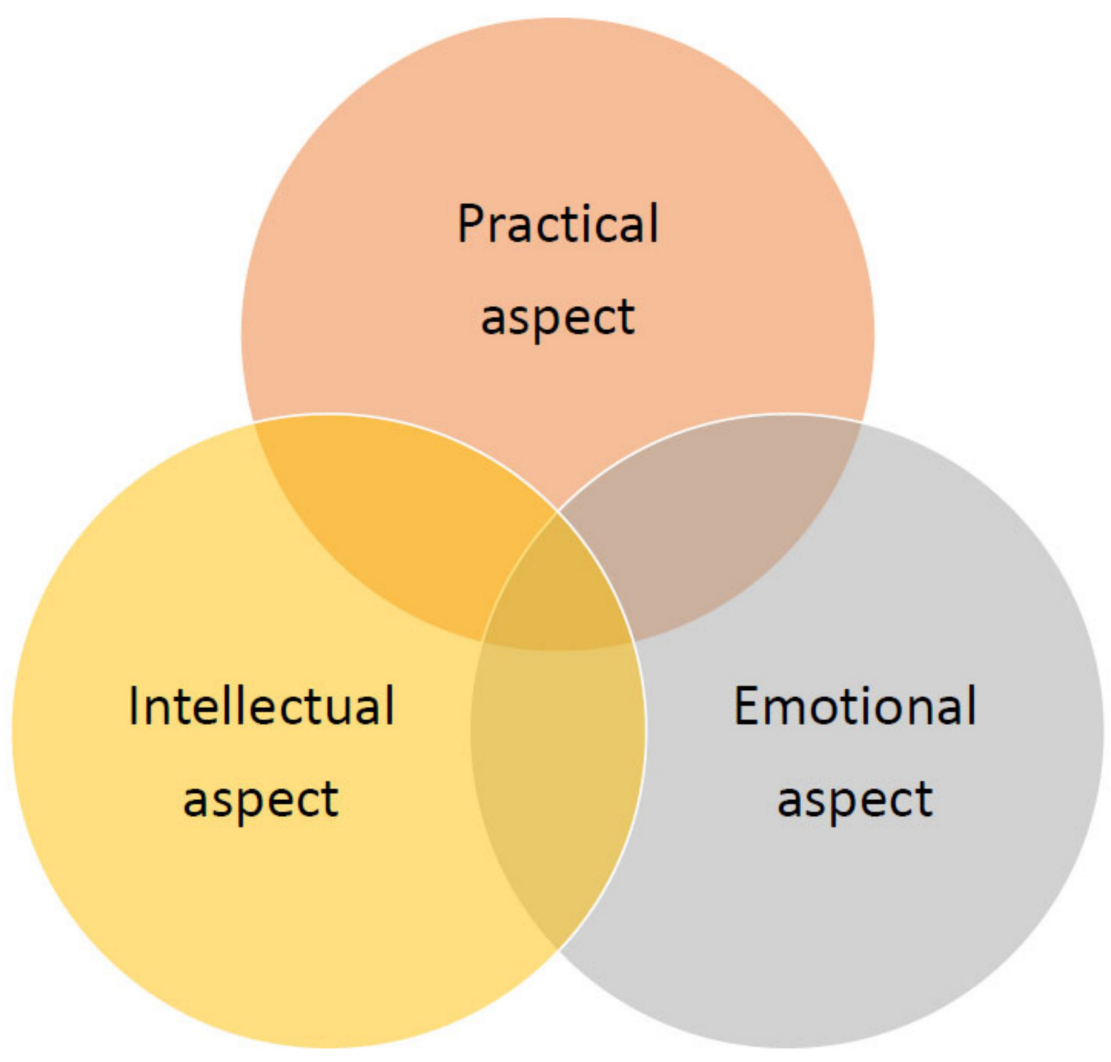

Figure 1. Aspects of a sustainability commitment.

Choosing teaching content ("facts") is not a value neutral process, as the selection of facts and descriptions of the world always involve value judgements [45]. Teaching content is not just a matter of which knowledge should be learned, but also includes paying attention to the values that accompany the subject content, the teaching methods that will be used and the teachers' aims (the "companion meanings") [46,47]. An important principle for the choice of content is that facts, examples, and resources should be obtained from various sources. Another is that teachers' choices of the "what" content should include a critical perspective or standpoint in the sustainability learning process. Although we acknowledge the insights into the development of a critical perspective on the teaching content that Klafki has offered, we also want to draw attention to postcolonial and decolonial perspectives as critical modes that can illuminate the ethical principle of responsibility for others and offer alternative perspectives on international development by challenging ethnocentrism and addressing issues of complicity [48-50]. Other examples are post-humanist perspectives that stress humans' complicity in the significant damage to ecosystems, ethical relations with more than human beings [51-53] and critical materialist perspectives that take the historical and critical commitments of environmental education seriously [54]. Perspectives such as these can help teachers and educators to go deeper into the causes and roots of events and engage students in thoughtful communication, thus opening up the possibility for a praxis that supports an ethical and complex approach to the teaching of sustainability issues and evokes new questions and possible responses (e.g., what is emphasized and what is marginalized?). A critical perspective can also be a useful tool in the process of choosing teaching content that will help teachers to identify the kind of knowledge and skills that will enable students to make important choices for sustainable transformation. 
However, knowing about the world is not enough. Students also need to relate to/position themselves to this knowledge and consider their role in a sustainable future [55]. This can find expression in epistemic, ethical, and political ways. The epistemic way means knowledge about how the students' own lives are connected to the world, what they depend on and how they influence the world (i.e., consumption, ecological footprint). Ethical ways of relating to the knowledge gained include adopting different ethical principles and ideas about rights and obligations, as well as rational thinking and standpoints concerning good values and right actions, i.e., the morally right way of living your life (including questions about the intrinsic value of biodiversity, the rights of future generations, obligations to people in other parts of the world etc.). Students also need to position themselves politically in relation to the knowledge they have learned and reflect on different conflicting ideas about a just and equal society (i.e., a socially just allocation of natural resources, democratic decision-making, and distribution of power).

From a Deweyan perspective, an intellectual aspect can be considered to be a "rational phase of reflective inquiry" [6] (p. 209), i.e., reflective inquiry as a kind of thinking. However, that does not create a genuine engagement unless students also have opportunities to emotionally grapple with sustainability problems and relate them to their own lives.

\subsection{The Emotional Aspect}

Dewey [10] argues that in a vital and living experience emotions are not just things that happen to us, but that they actually play an important role in our lives and in rational thinking. Students' emotional responses to disciplinary knowledge and their relations to sustainability issues are crucial for a deeper commitment to and understanding of how sustainability issues relate to them personally. Students' emotional responses can be of a political nature (relating the future organization of a just and equal society/world) or moral nature (relating to responsible and caring relationships between humans or between humans and animals/plants/ecosystems).

Several researchers in the ESE field have highlighted the importance of emotions as a moving force and that reason (knowledge) and emotion are mutual and inseparable when learning about sustainability issues [56-61]. Hicks and Bord [57] hold that an emotional response "appears to occur when knowing shifts from being something intellectual and detached to a personal and connected knowing./ ... /Most importantly the emotional responses experienced by students need to be accepted and seen as part of a shared experience" (415f.). Similarly, Ojala [58,59] maintains that learning about sustainability problems affects and stirs up emotions and that this is not something that teachers should try to get rid of or try to "change". Drawing on earlier research in the field, Ojala [59] cautions against trying to steer students' emotions and categorize them as right or wrong, because that can turn education into indoctrination [60,62]. A crucial point that Ojala makes, and that is applicable to a sustainability commitment, is that emotions are not the enemy of reason but rather an important part of it. Of course, negative emotions such as denial of the seriousness of climate change can be negatively related to engagement [63]. However, other negative emotions, such as worrying about climate change and worsening inequality, can actually be a driving force for critically reflecting on, discussing and perhaps challenging some of our assumptions about the way we live and the way we interact with each other and the environment. Thus, worry can be a first step towards a wider public interest. Consequently, as teachers we need to raise awareness of emotion regulation strategies that promote students' critical awareness and engagement, respond to their feelings and worries and constructively try to handle and cope with emotions [59]. Equally, it is important to promote students' critical emotional competence that also acknowledges structural and cultural factors. For example, treating emotions and coping strategies as entirely private affairs might counteract the transition towards a more sustainable society. As Ojala [59] argues, a strongly individualized approach to emotions prevents young people from developing a critical and alternative view of society. 
Drawing on Todd [64] and Mouffe [65], Sund and Öhman [60] have argued for the importance of dealing with conflicts passionately in ESE, given that emotions are key "drivers" for creating relations to the world and taking a political stand for or against something. They also conclude that our values and principles continuously change in relation to specific and situated contexts. Following Todd [64], they claim that this change is provoked by others in all their differences and is a potential source of new thought. In their empirical case study, Håkansson and Östman [56] also show how affection can be transformed into political emotions in teaching and learning settings and form the basis of an inquiry leading to political meaning-making.

Emotions in the form of moral reactions can also be grounds for ethical reflection. The teaching content itself can evoke a spontaneous moral response, but "it can also be the case that the teacher deliberately wants to provoke a moral experience, for example, by showing a movie or reading a text which concerns the students and arouse their emotional responses" [66] (p. 98). To start teaching concrete cases based on students' moral experiences connects to Dewey's view of morality as lived practice and contextual [67]. What is experienced depends on what we bring to a situation. Habits and ways of life determine how we (inter)act in a situation and coordinate our actions with others: "The emotional aspects of experience are always the result of a transaction between the organism and the environment. Emotional appreciation is about something that in a situation is experienced as having certain qualities" [67] (p. 223). Thus, morality arises and takes shape in relation to others, and here emotions can have an important function.

\subsection{The Practical Aspect}

Knowledge and emotions are not much use when it comes to a sustainable transformation if you do not know how to act. The third aspect of our model for a sustainable commitment is therefore the practical and focuses on students' actions and action competencies. Sustainable Development Goal 4.7 points to the important responsibility of schools to develop students' abilities to play an active part in the transformation towards a sustainable society. In this transformation, and as mentioned previously, what kind of knowledge will be needed is by no means obvious. Therefore, students need to be given an active role as producers of knowledge and teachers in turn need to help them to develop their abilities and desires to play an active role in this transformation. Knowing how to act and being able to act are essential components of a sustainability commitment. Transformative actions can be moral (actions at the individual level, such as saving electricity and water by changing your lifestyle) or political (actions that relate to societal change, e.g., writing an email to a politician). Furthermore, actions can be deliberative (discussing and affecting), practical (sorting waste), or innovative (starting an environmental group).

The practical aspect connects to the foregoing discussion of a pragmatic understanding of experience and Dewey's view of action as a crucial part of knowledge, rather than something that is passively perceived $[8,68]$. As explained by Dewey [10], we encounter others in "our dealings with things", through actions and their consequences. Therefore, in the suggested model we depart from the view that students learn in and through their interactions with their environment.

As already indicated, action competence has been a concept in the ESE field since the 1980s. This approach points to teaching "that can help students develop their ability, motivation and desire to play an active role in finding democratic solutions to sustainability issues" (cf. [23,24]) (p. 62). A key notion in this concept is the difference between "activity" and "action", where an action is focused on solutions to a problem and has a perspective that directly enacts change. Mogensen and Schnack [24] also underline the importance of considering the educational significance of the objective content of the actions, the circumstances to which the actions are addressed, and that actions (as distinct from activities) are qualified by the intentions of the agent and by being conscious and purposive.

Furthermore, Mogensen and Schnack [24] argue that the notion of action in action competence has philosophical and educational significance. Action competence refers to 
an educational ideal and is thus closely "linked to democratic, political education and to a radical version of the notion of "Bildung'" [24] (p. 60). The democratic perspective implies that the concept is not context defined, in the sense that it points towards specific actions or visions for a sustainable future. Nonetheless, it is prescriptive in that it relates to issues in an impartial and critically responsible manner and bases our actions on the possible and relevant answers we find-thus supporting open-ended and pluralistic forms of education. We regard the practical aspect to be in line with this definition.

\section{The Role of the Teacher: Teacher Moves}

Teachers play an essential role in students' development of a critical understanding of sustainability issues and, ultimately, in their awareness and interest in relation to living sustainably. As Dewey [11] claims: "Teachers are the agents through which knowledge and skills are communicated and rules of conduct enforced" (p.18). The task of the teacher is to select and present a certain content (Inhalt) and to guide, direct and navigate students' inquiries so that they make the content their own (Gehalt). In didactic theory, the teacher is seen as an autonomous reflective practitioner, where the curriculum constitutes the frame for the teacher's choices [42]. This means that "Teachers should not just be able to choose and practice appropriate methods to teach a certain given content but also be able to understand which content should be selected within the frames given by society and the circumstances set by their school and their students" [69] (p. 146).

Teachers' didactic choices can be understood as teacher moves [70]. Teacher moves are the different actions that a teacher carries out to create a learning environment for the students. These moves relate to teachers' didactic choices of content and methods and their didactic reasoning. The moves can basically be of two kinds: staging an inquiry (the actions that teachers make to encourage the students' own activities and to initiate an inquiry process) and scene-setting (teachers' actions that guide, direct, and navigate students in ongoing inquiry processes).

Thus, a teacher's role in the development of a sound commitment can be understood as staging and scene-setting moves that are directed towards the intellectual, emotional, and practical aspects of sustainability commitment (see Figure 2). This relates to the choices that teachers make in their planning and the actions they carry out in the classroom in their direct interactions with students. It is difficult to overestimate the importance of the teacher in the organizing of the conditions that will enhance the students' experiences (and the subject-matter of the study). Teachers are crucial for creating a balance between the different aspects of commitment and for challenging the students to deepen their standpoints and arguments [71,72].

Even though we frame these moves as stemming from the teacher, it is important to highlight that they are relational and dynamic, which means that the moves are not isolated actions in relation to the students' actions. What teachers do in their classrooms (their moves) should in this sense be understood in relation to their didactical choices and the students' responses and answers to the teachers' moves (we refer to this as reflective interaction between participants, teachers, and students). The literature on teacher professionalism points out that a key aspect of being a professional is being able to act from certain aims in relation to the specific context in which one acts [73,74]. This is one of the reasons why we think it is important to illustrate the moves as stemming from the teacher-the teacher has some didactical aims with the lesson, while at the same time the particular meaning and the specific routes the moves take are dependent on the students' actions and responses. Thus, the moves should be understood as context dependent. 


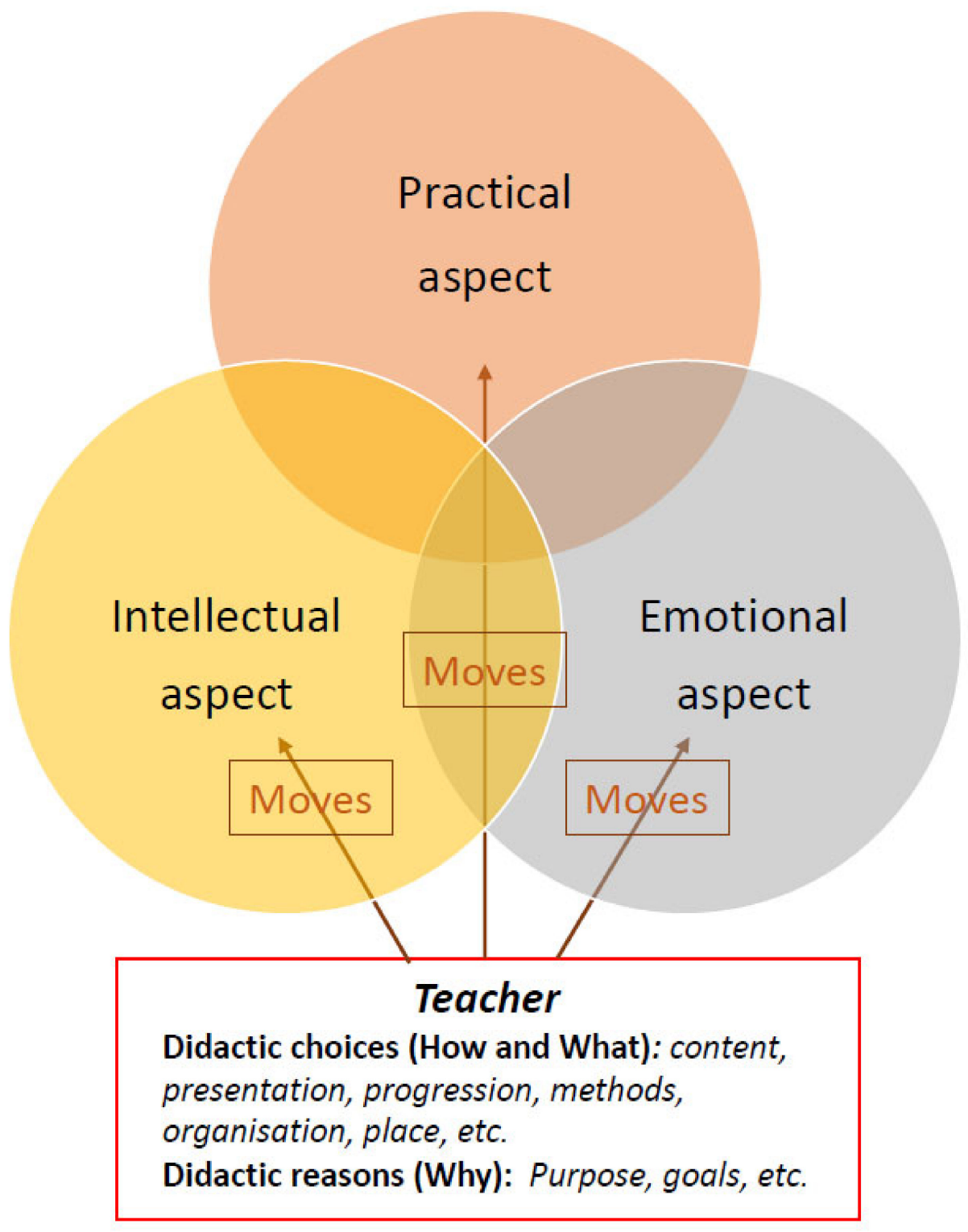

Figure 2. Teachers' moves in relation to students' sustainability commitment.

\section{Empirical Illustrations: Teaching for a Sustainability Commitment}

In this section, we use empirical examples to illustrate the different aspects of the suggested model and their associated processes. These empirical illustrations are meant to highlight how teachers work towards supporting the creation of students' sustainability commitment in their practice. It should be noted, however, that not all teachers are equally able to develop such skills, nor equally motivated to develop competence in their students. The varying quality and conviction of individual teachers is not addressed here, but we demonstrate how teachers can encourage their students and set the scene for their inquiries in relation to the various aspects of a sustainability commitment. Rather than ideals these examples show what teachers do in everyday teaching situations.

\subsection{The Intellectual Aspect in Practice}

This first example shows how a teacher encourages the development of the intellectual aspect of her students' sustainability commitment (Box 1). In this lesson, the students (year 11) are given the opportunity to explore the document entitled The United Nations Declaration on the Rights of Indigenous Peoples (UNDRIP) in a global politics course. During the lesson, the students are encouraged to identify conflicts relating to this declaration, 
discuss different arguments and state their own standpoints. As preparation, the teacher, Alice, posted UNDRIP's 46 articles on the school's web portal together with a news article explaining the fact that four countries first voted to oppose the resolution but later adopted it. The lesson begins with Alice reminding the students that four countries voted against the declaration: "And their claim was that this threatened their national sovereignty. So, I want to see if you can argue for their case. So, four countries voted no to this declaration. Which countries were they? Does it have anything to do with the colonial past?" She then reads the news article out to the class and tells the students: "So, I want you to try to map out what the conflict is./ ... /Which articles are problematic or ... spark conflicts? And discuss the pros and cons." The students then discuss how they can best map out the conflicts and find that two of the Articles in the Declaration have been criticized (Articles 26 and 28). At the end of the lesson Alice returns to the question of conflict:

Box 1. Example of the intellectual aspect in practice.

Alice: Alright folks. OK. What is the conflict about do you think? What is the conflict?

Duha: The indigenous people are not getting what they deserve.

Alice: Mm. Discrimination. And this is true. I mean, if you look at this population in comparison to the general population, generally speaking, indigenous peoples have a lower life expectancy, poorer health ... don't have equal access to health care, or education. They are marginalized in many, many ways, which is true.

Elaine: But I guess the problem is that ... . I think they want to compensate the indigenous people, but then who decides what kind of compensation is right, how much, and to who? Like who is ... Alice: Yes. Who are the indigenous people? We were talking about it here in this classroom. What does it really mean?

Elaine: Who is supposed to get compensation? And also, if they want their land back then they're asking the US to take land from someone else and give it back to them. Basically, they are saying that what they did a long time ago was wrong. So, it's a little bit like ... I understand why they should have that land, but as it was so long ago, it's also a little bit ... Like you can't really punish me for what my grandfather did. But I'm not saying that they shouldn't be compensated. Obviously, they should.

Alice: Mm. But the problem here is ... We will come to that when we get to the individual articles. Have I overlooked any of the points that you addressed? Like, can you punish landowners today for the sins of the past? Whose land is it? Can you take land and say "OK, you guys, you don't have enough, you guys have enough?" Who are the indigenous peoples? Which group are we talking about? What is their definition? I mean, should we read the actual Declaration to see what it doesn't say. It just launches straight into "The indigenous peoples have the following rights". But of course, it is sad. We are meant to do something about historical injustices, right? I mean, we won't have a sustainable society if we don't address these imbalances, if we don't do something.

/... /

Elaine: But then what if the indigenous people don't think it's enough? How will they be compensated, if not with land? With money? Or some other rights? It's like ... I think that saying that they deserve compensation just brings up hundreds more questions to be answered.

Alice: Yes. It's a super complex issue. But on the other hand, if you don't address these imbalances $\cdots$

Millie: Then they will not be addressed ...

Alice: Yes. That means a risk to the status quo as well. Maybe. Yes.

Millie: Yes. I was just going to say the minority of the country, they don't ... they can't really fight for themselves. Let's be honest. They can't really fight for themselves, so I don't really think ... They're going of course to demand more. I think almost everyone will demand more, but I don't think anyone would care about the amount. So, this doesn't really ...

In the sequence in Box 1 the students explore the meaning of "indigenous" and try out different definitions based on a certain content presented to them by their teacher. The excerpt gives examples of how students can position themselves to the knowledge they have acquired ethically ("indigenous people are not getting what they deserve"), epistemically ("I understand why they should have that land, but as it was so long ago, it's also a little bit ... Like you can't really punish me for what my grandfather did") and 
politically ("Let's be honest. They can't really fight for themselves"). It is important to notice here that the ways in which the students position themselves are interconnected. Not only does Alice guide the students towards a body of (intellectual) knowledge that they need to understand (indigenous rights, land ownership etc.), she also points to a moral problem and brings this intellectual knowledge into relation with an ethical dimension where the students need to consider right and wrong, good and evil. For Elaine, this starts a process of inquiry as she gets involved in reflections on moral issues.

\subsection{The Emotional Aspect in Practice}

In the situation referred to above there are no obvious emotional responses. The emotional aspect is more salient in the subsequent example (Box 2). Here, the same teacher and group of students discuss and research the difference between a state and a nation, where the question of belonging evokes strong reactions.

Box 2. Example of the emotional aspect in practice.

Alice: OK. So, what is a state and how does it differ from a nation?

Elam: A state has an official government that exercises power ... they have a monopoly of force... Alice: Yes. So, it's an actor in global politics. It's a political entity that has sovereignty of its territory, and it also engages in relations with other states, right? It's a political organization with a government. Somebody is in charge. OK, what is a nation state then? No, I'm sorry. The nation first. Duha: A body of people united by a common descent, history, culture or language.

Alice: So, it's a unity among people. They feel that we belong together ... . How many here have Swedish passports?

[Most students raise their hands]

Alice: So ... majority. OK. So, for us Sweden would be our state. This is where we are citizens. The question is: Is this where we belong? Is this where we feel ... We feel unity with Sweden. We share the same culture, we share the same language, we share the same history. What do you think?

Duha: No!

Alice: No?

Duha and Millie: Hahahaha!

Alice: What? [students laughing]

Duha: I don't have the same culture as a Swedish person ...

Millie: (whispering) My God this is hard ...

Alice: OK. Would it be difficult for you to say that you share unity with Sweden, with Swedish ... ? Duha: ... people? Yes!

Alice: Would it be very alien to you ... ? I was having this conversation with my mother the other day actually .... .

Duha: ... because, most Swedish people are Christians. I'm not a Christian.

Alice: Yes ... but most Swedish people are super secular. They don't care!

Millie: Yes...

Duha: OK, I don't know!

Alice: But I mean, it's an interesting feeling. It's a feeling. This is what I mean. This is the definition. This is the difference between a state and a feeling, really! This is a feeling of unity. You belong to a nation, and nobody can argue with that, you know. That is your perception of something. Whereas your state ... You have a Swedish passport, right?

Duha: Yes.

Alice: Yes. So, without question you are part of the Swedish state. You are a citizen. You have rights and obligations under the Swedish state. Whether or not you feel unity with the Swedish state, that's another question. That's for no-one else to decide but you. But it's still interesting, isn't it? Now, I was talking to my mother. She's been here since 1969 I think it was, the first time she came here, in her mini skirt in the 1960s, in the winter, freezing her ass off. And she was saying the same thing, like "After all these years, I have grandchildren, I have children in Sweden. Do I feel Swedish?", and she said "Yes, to some extent. But man, Swedish people are cold. Man, I can't ... It's hard to talk to them. I have friends, but ... ". I was like "Yeah, yeah. Don't judge them too harshly. They're a bit shy". But it's interesting. So, what is a nation state then?

In staging this discussion, the teacher, Alice, deliberately evokes students' emotions yet also "picks up" emotional responses and offers guidance. These emotions have both 
moral and political implications for the specific understanding of the situation and the question of belonging. In the above example, the student Duha spontaneously reacts to Alice's description of feelings of unity and a common culture that includes a moral obligation to her (Islamic) culture. This involves Duha's emotional response to the politics of belonging, the difference between cultural identity, or the feeling of belonging to a group and having country citizenship. Based on Alice's response, Duha questions her own standpoint, which makes it possible to discern how morals are involved in the situation and in the interplay with others. Alice shows that these emotional responses are accepted and makes them part of a shared experience. By setting the scene in this way she deepens the students' processes of inquiry and supports the idea that even though the students ${ }^{\prime}$ emotions may not always be possible to explain or defend by rational argument, they are legitimate and important ("This is a feeling of unity. You belong to a nation, and nobody can argue with that, you know. That is your perception of something"). At the end of the excerpt, Alice takes a meta-perspective on what it means to feel unity and belong to a nation and encourages the students to reflect on their own and others' moral experiences, formulate and consider arguments of their position and test their validity in their social contexts.

The sequence in Box 2 exposes the important role that emotions can play in students' discussions. It shows how students create emotional relations to global politics and how these relations lead to the students taking a stand on a certain issue. Furthermore, it is an example of how a teacher can use emotions as a driving force in students' inquiries and support their development of a sustainability commitment.

\subsection{The Practical Aspect in Practice}

The practical aspect refers to activities and actions that make encounters with the reality outside the classroom possible, i.e., actually doing something and trying to make a change in a sustainable direction. This aspect is here exemplified by a group of students and their teachers working with entrepreneurship as an extra-curricular activity (year 11, Business Management and Economics Program) as part of an exchange/school visit program between Sweden and Tanzania. The purpose of the visit was for the Swedish students to run workshops and offer the Tanzanian students the opportunity to train and develop their creativity and entrepreneurship by working on sustainable innovations and business ideas, and creating a business plan. These activities were central to the exchange program. After the visit, the Swedish students shared their experiences, feelings, and images with other students at their own school.

After the visit, one of the participating teachers and a group of three students were interviewed. The teacher Peter was asked about what he thought the students had learned from the exchange (Box 3).

Box 3. Example of the practical aspect in practice.

Peter: I believe they have learned a lot. And to be honest, I don't think it's about a certain content knowledge or whatever, but more about humanity/humanness and the emotions related to that. Also that they discovered new sides of themselves ... That is perhaps what they learned the most ... At least when we have talked about it afterwards. Like, "I didn't think I would react in that way", or "This has made me interested in ...", things like that/... / I think that they would probably say a personal change...

In the excerpt in Box 4 the students are asked to compare their experiences from the visit with what they have learned in subjects such as the social- and natural sciences. 
Box 4. Example of the practical aspect in practice.

Thomas: You can try to read about different things, about poverty, about how economies and executive boards and societies work, but you will never be able to connect at an emotional level to what you have been through. If you've been there and experienced it for yourself ... it's like ... You will never be able to understand this seed, this core of how it works if you haven't been there ...

Tilda: I mean we have all taken part in the education about extreme poverty and what it's like to live below the poverty line, but you will never be able to really understand it until you have been there yourself and seen it from your own perspective. Or I mean, yeah, before you are actually there. It's so incomprehensible because it's so different to your own daily life. And that is why it is so hard. It is so hard to grasp from a lesson compared to what it's like in reality.

This example highlights the importance of practical activities that make it possible for students to engage in real problems and interact directly with others. The responses of the teacher and the students reveal how the study visit made the students clarify, rethink and sometimes re-formulate their own values (and actions). The excerpts show how learning through these activities involves and is intimately connected with emotions ("I believe they have learned a lot ... about humanity/humanness and emotions related to that") and intellectual insights ("You will never be able to really understand it until you have been there yourself and seen it from your own perspective"). The excerpts also point to the moments when we "take in" the world in its difference. Taking in difference in a concrete and practical context affects these students deeply in a way that is transformative and allows them to gain new insights and deepen their sustainability commitment.

\section{Discussion}

The purpose of this article has been to propose a model that describes and frames a sustainability commitment and while providing a critical perspective on ESE practice offering a framework for selecting content and methods when teaching sustainability issues. Using a retroductive method, we have developed this model through an interplay between Nordic and German didactic theory, John Dewey's pragmatic philosophy, and several empirical studies on ESE practice.

The model suggests that sustainability commitment should be a common goal for ESE and that a sound commitment is situated at the intersection of the intellectual, emotional, and practical aspects of sustainability (Figure 3). The relationship between these aspects is reciprocal. If one or two of the aspects are missing, or if there is an imbalance between them, the commitment risks being misleading or vague.

The intellectual aspect is essential for giving the commitment scientific rigor and a critical stance. A sustainability engagement based on emotions may lack critical intellectual insights derived from e.g., postcolonial and decolonial studies. Such an engagement could run the risk of naïve activities characterized by "salvationism" and "ahistoricism", i.e., activities that portray other people as being in need or frame help as a burden of the fittest and thus fail to take the historical past of oppression and exploitation into account $[48-50,75]$. Without a critical perspective, there is a risk that the political and ethical nature of sustainability issues will be hidden. An educational approach that assumes a form of consensus on sustainable development overlooks the fact that power relations are constitutive of the social and that conflict and antagonism cannot be eradicated [60]. It is, therefore, essential to integrate critical perspectives into the learning process and in this way develop students' competence to identify and analyze ethical and political tensions and provide them with tools to handle conflicts in constructive ways.

On the other hand, if there is a lack of emotional involvement in sustainability issues, they become detached from the person. The actions may be reflected activities but there is no driving force for change. As shown by Ojala [59], when treated in the right way, emotions such as hope and fear are essential if students are to become dedicated and actually want to do something. 


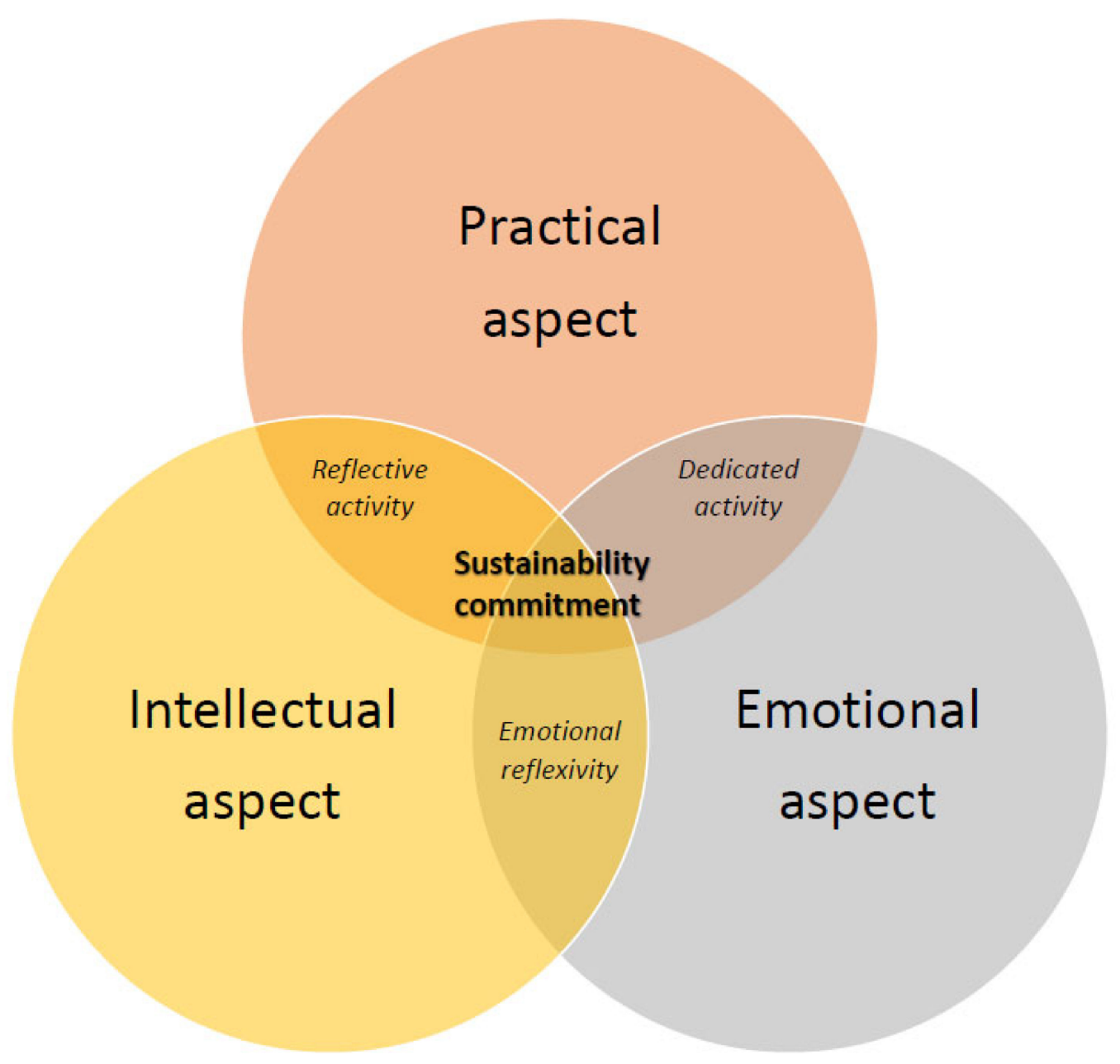

Figure 3. Sustainability commitment as the intersection between intellectual, emotional, and practical aspects.

Apart from knowledge about the world, it is also important for the intellectual aspect to include inquiries into the students' own epistemic, ethical, and political positions in relation to this knowledge. If this is missing, sustainability issues may become distant issues that do not relate to the students' lives and concerns. Together, the intellectual and emotional aspect can create an "emotional reflexivity" - a personal engagement anchored in scientific knowledge and ethical and political insights. This can be seen as a reflective approach that could start a careful examination of the collective "root" narratives that we are a part of and where such understandings come from [49,76].

To play a more active role in providing a sustainable transformation of society, it is also necessary to be knowledgeable about appropriate and effective actions for change and have the willingness, confidence and skills to carry them out [25]. However, an action is not just a physical activity, but also involves deciding what to do through a problem-solving process [23]. The practical is thus an indispensable part of a sustainability commitment, although too much emphasis on this may turn ESE into "solutionism" and "instrumentalism". There is therefore a danger that teachers who are attached to actions may get caught up with "doing something" and finding solutions to ongoing or emerging sustainability challenges. However, as Jensen and Schnack [23] put it: "the task is not to solve the problems of the world by 'using' the pupils" (p. 484).

Although a sustainability commitment is a common goal, we claim that the results of the students' inquiries should be an open question, in line with a pluralistic approach to ESE [37], i.e., the ethical and political standpoint on sustainability issues should be the individual student's concern. The role of the teacher is to support the development of a deep engagement anchored in scientific knowledge through a critical inquiry into 
different alternatives without privileging a specific opinion. If we believe in a democratic transformation towards a sustainable society, we should allow for a plurality of standpoints in schools. However, then again, an over-focus on a concern with a plurality of perspectives without a critical approach could mean that a sustainability commitment misses the point.

In relation to previous significant attempts to define the content of sustainability awareness and interest, such as the key competence approach $[14,15,17]$ and the action competence approach [23], we have considered the question from a didactic point of view. We have put teaching practice and the learning process in the foreground and asked ourselves how meaningful competencies can be fostered. We also agree with Shephard et al. [77] who have raised concerns about the usefulness of the terms "competence" and "capability". They highlight that existing frameworks all too often fail to distinguish between the outcomes that students are expected to achieve and their motivation to enact them, and the pedagogical approaches designed to achieve them. These authors conclude that outcomes as competencies or capabilities "that fail to describe in educational terms the pedagogical imperatives of engagement and of assurance of learning, are unlikely to help the mission of ESD" (p. 544). Similarly, Vare et al. [78] points to the risk that an all too detailed qualification template run the risk to "atomize learning in a way that runs counter to the holistic principles of sustainability" (p. 1).

Furthermore, we have provided a theoretical basis in didactic theory and Dewey's pragmatism and developed the suggested model in an interplay with empirical studies of ongoing practice. We have presented a structure that shows how the different components of a commitment are interconnected and are not simply competencies that people should "have" to solve sustainability problems. The action competence approach [23] has contributed important normative perspectives on what competence and action can and should mean in educational practice. The focus of this approach lies mostly on how knowledge about sustainability issues can be transformed into an actionable phase and how actions can contribute to change. In relation to this educational ideal, we have developed a holistic model for the content of a sustainability commitment that describes how actions relate to students' intellectual understandings of and emotional responses to sustainability issues. It is our hope that these additions will help teachers to organize students' inquiries into sustainability issues in a more meaningful way.

In this article, we have only touched on the essential didactic question of how-the best methods for teaching for a sustainability commitment. Furthermore, we have mostly argued for the different components of sustainability commitment, but have to a lesser extent stressed the depth of students' knowledge, awareness, and skills that is required for them to qualify as sustainability citizens, who in Arjen Wals' words are "able to interrogate resilient unsustainability and who can participate in the co-creation of new systems and associated routines that appear, at least for the moment, more sustainable than the ones in need of replacement" [19] (p. 34). What we therefore would like to encourage is further didactic research that deepens the knowledge about the relation between certain teaching efforts and students' development of a sustainability commitment. Presently, too much of this research consists of occasional dives into classroom practice, where far-reaching conclusions are drawn from single lessons. What we think is required here is longitudinal studies covering the interplay between teaching and students' development over several years, combined with in-depth interviews to determine how young people reason about, feel about, and value the urgent, complex, and severe sustainability challenges that we are facing today.

Author Contributions: J.Ö. and L.S. have together developed the theoretical model, conceived and designed the study, analyzed the data, and written the paper. Both authors have read and agreed to the published version of the manuscript.

Funding: This research was funded by the Swedish Research Council, grant number 2017-03468.

Informed Consent Statement: Informed consent was obtained from all subjects involved in the study. 
Data Availability Statement: Data available on request due to ethical restrictions. The data presented in this study can be available on request from the corresponding author.

Conflicts of Interest: The authors declare no conflict of interest.

\section{References}

1. UNESCO. Education for Sustainable Development Goals Learning Objectives; UNESCO: Paris, France, 2017. Available online: https:/ / unesdoc.unesco.org/ark:/48223/pf0000247444 (accessed on 15 February 2020).

2. Aguilar, O.M. Examining the literature to reveal the nature of community EE/ESD programs and research. Environ. Educ. Res. 2018, 24, 26-49. [CrossRef]

3. Vare, P.; Scott, W.A.H. Learning for a change: Exploring the relationship between education and sustainable development. J. Educ. Sustain. Dev. 2007, 1, 191-198. [CrossRef]

4. Scott, W. Sustainable schools and the exercising of responsible citizenship-A review essay. Environmental Educ. Res. 2011, 17, 409-423. [CrossRef]

5. Hudson, B.; Meyer, M.A. (Eds.) Beyond Fragmentation: Didactics, Learning and Teaching in Europe; Barbara Budrich Publishers: Leverkusen, Germany, 2011.

6. Dewey, J. How We Think; Prometheus Books: New York, NY, USA, 1910/1991.

7. Dewey, J. The Quest for Certainty. In The Later Works of John Dewey, 1925-1953, Vol. 4; Boydston, J.A., Ed.; Southern Illinois University Press: Carbondale/Edwardsville, IL, USA, 1929.

8. Dewey, J. Experience and Nature; Dover Publications: New York, NY, USA, 1929/1958.

9. Dewey, J. How we think. A restatement of the relation of reflective thinking to the educative process. In The Later Works of John Dewey, 1925-1953, Vol. 8; Boydston, J.A., Ed.; Southern Illinois University Press: Carbondale/Edwardsville, IL, USA, 1933.

10. Dewey, J. Art as Experience; Perigee Books: New York, NY, USA, 1934/1980.

11. Dewey, J. Experience and Education; The Kappa Delta Pi Lecture Series; Simon \& Schuster: New York, NY, USA, $1938 / 1997$.

12. Andersson, P.; Öhman, J. Contributions from transactional analyses of teaching and learning processes in situ. In Deweyan Transactionalism in Education: Beyond Self-Action and Inter-Action; Garrison, J., Öhman, J., Östman, L., Eds.; Forthcoming: Bloomsbury, UK, 2021.

13. Van Poeck, K.; Östman, L.; Öhman, J. (Eds.) Sustainable Development Teaching: Ethical and Political Challenges; Routledge: Milton Park, UK; New York, NY, USA, 2019.

14. Barth, M.; Godemann, J.; Rieckmann, M.; Stoltenberg, U. Developing key competencies for sustainable development in higher education. Int. J. Sustain. High. Educ. 2007, 8, 416-430. [CrossRef]

15. Rieckmann, M. Future-oriented higher education: Which key competencies should be fostered through university teaching and learning? Futures 2012, 44, 127-135. [CrossRef]

16. Wiek, A.; Withycombe, L.; Redman, C.L. Key competencies in sustainability: A reference framework for academic program development. Sustain. Sci. 2011, 6, 203-218. [CrossRef]

17. Wiek, A.; Bernstein, M.J.; Foley, R.W.; Cohen, M.; Forrest, N.; Kuzdas, C.; Kay, B.; Withycombe Keeler, L. Operationalising competencies in higher education for sustainable development. In Routledge Handbook of Higher Education for Sustainable Development; Barth, M., Michelsen, G., Thomas, I., Rieckmann, M., Eds.; Routledge: London, UK, 2016; pp. 241-260.

18. Rieckmann, M. Learning to transform the world: Key competencies in Education for Sustainable Development. In Issues and Trends in Education for Sustainable Development; Leicht, A., Heiss, J., Byun, W.J., Eds.; UNESCO Publishing: Paris, France, 2018; pp. 39-59.

19. Wals, A. Beyond Unreasonable Doubt: Education and Learning for Socio-Ecological Sustainability in the Anthropocene; Inaugural Address Held upon Accepting the Personal Chair of Transformative Learning for Socio-Ecological Sustainability at Wageningen University on 17 December 2015; Wageningen University: Wageningen, The Netherlands, 2015. Available online: https:/ / arjenwals.files. wordpress.com/2016/02/8412100972_rvb_inauguratie-wals_oratieboekje_v02.pdf (accessed on 12 January 2020).

20. Leicht, A.; Heiss, J.; Byun, W.J. (Eds.) Issues and Trends in Education for Sustainable Development; UNESCO Publishing: Paris, France, 2018.

21. Willbergh, I. The problems of 'competence' and alternatives from the Scandinavian perspective of Bildung. J. Curric. Stud. 2015, 47, 334-354. [CrossRef]

22. Wilhelm, S.; Förster, R.; Zimmermann, A.B. Implementing competence orientation: Towards constructively aligned education for sustainable development in university-level teaching-and-learning. Sustainability 2019, 11, 1891. [CrossRef]

23. Jensen, B.B.; Schnack, K. The action competence approach in environmental education. Environ. Educ. Res. 2006, 12, 471-486. [CrossRef]

24. Mogensen, F.; Schnack, K. The action competence approach and the 'new' discourses of education for sustainable development, competence and quality criteria. Environ. Educ. Res. 2010, 16, 59-74. [CrossRef]

25. Sass, W.; Boeve-de Pauw, J.; Olsson, D.; Gericke, N.; De Maeyer, S.; Van Petegem, P. Redefining action competence: The case of sustainable development. J. Environ. Educ. 2020. [CrossRef]

26. Peirce, C.S. Pragmatism as a Principle and Method of Right Thinking: The 1903 Harvard. Lectures on Pragmatism; Turrisi, P.A., Ed.; State University of New York Press: Albany, NY, USA, 1903/1997. 
27. Peirce, C.S. The Collected Papers of Charles Sanders Peirce; Reproducing Vols. I-VI ed.; Hartshorne, C., Weiss, P., Eds.; Harvard University Press: Cambridge, MA, USA, 1931-1935; Vols. VII-VIII ed.; Burks, A.W., Eds.; Harvard University Press: Cambridge, MA, USA, 1958; The Electronic Edition of the Collected Papers of Charles Sanders Peirce 1 June 1994. Available online: https:/ / colorysemiotica.files.wordpress.com/2014/08/peirce-collectedpapers.pdf (accessed on 15 April 2020).

28. Glynos, J.; Howarth, D. The retroductive cycle: The research process in poststructuralist discourse analysis. In Discourse, Culture and Organization: Inquiries into Relational Structures of Power; Marttila, T., Ed.; Palgrave: London, UK, 2018 ; pp. $105-125$.

29. Walsh, C.E. Decolonialty in/as praxis. In On Decolonialty. Concepts, Analytics, Praxis; Mignolo, W.D., Walsh, C.E., Eds.; Duke University Press: Durham, UK; London, UK, 2018; pp. 15-102.

30. Öhman, J.; Östman, L. Different teaching traditions in environmental and sustainability education. In Sustainable Development Teaching: Ethical and Political Challenges; Van Poeck, K., Östman, L., Öhman, J., Eds.; Routledge: Milton Park, UK; New York, NY, USA, 2019; pp. 70-82.

31. Hopmann, S. Restrained teaching: The common core of didaktik. Eur. Educ. Res. J. 2007, 6, 109-124. [CrossRef]

32. Deng, Z. Content, Joseph Schwab and German Didaktik. J. Curric. Stud. 2015, 47, 773-786. [CrossRef]

33. Hudson, B. Approaching educational research from the tradition of critical-constructive didaktik. Pedagog. Cult. Soc. 2003, 11, 173-187. [CrossRef]

34. Klafki, W. Didactic analysis as the core of preparation of instruction (Didaktische Analyse als Kern der Unterrichtsvorbereitung). J. Curric. Stud. 1995, 27, 13-30. [CrossRef]

35. Hopmann, S. 'Didaktik meets Curriculum' revisited: Historical encounters, systematic experience, empirical limits. Nord. J. Stud. Educ. Policy 2015, 1, 14-21. [CrossRef]

36. James, W. Pragmatism. A New Name for Some Old Ways of Thinking. 1907. Available online: https://www.gutenberg.org/files/ 5116/5116-h/5116-h.htm (accessed on 22 May 2020).

37. Andreotti, V. Actionable Postcolonial Theory in Education; Palgrave Macmillan: New York, NY, USA; London, UK, 2011.

38. Andersson, E.; Öhman, J. Young people's conversations about environmental and sustainability issues in social media. Environ. Educ. Res. 2017, 23, 465-485. [CrossRef]

39. Andersson, P. Business as un-usual through dislocatory moments-Change for sustainability and scope for subjectivity in classroom practice. Environ. Educ. Res. 2018, 24, 648-662. [CrossRef]

40. Håkansson, M.; Östman, L.; Van Poeck, K. The political tendency in environmental and sustainability education. Eur. Educ. Res. J. 2018, 17, 91-111. [CrossRef]

41. Lidar, M.; Almqvist, J.; Östman, L. A Pragmatist approach to meaning making in children's discussions about gravity and the shape of the earth. Sci. Educ. 2010, 94, 689-709. [CrossRef]

42. Öhman, J.; Öhman, M. Participatory approach in practice: An analysis of student discussions about climate change. Environ. Educ. Res. 2013, 19, 324-341. [CrossRef]

43. Rudsberg, K.; Öhman, J.; Östman, L. Analyzing students' learning in classroom discussions about socioscientific issues. Sci. Educ. 2013, 97, 594-620. [CrossRef]

44. Sund, L.; Pashby, K. 'Is it that we do not want them to have washing machines?': Ethical global issues pedagogy in Swedish classrooms. Sustainability 2018, 10, 3552. [CrossRef]

45. Östman, L.; Van Poeck, K.; Öhman, J. Principles for sustainable development teaching. In Sustainable Development Teaching: Ethical and Political Challenges; Van Poeck, K., Östman, L., Öhman, J., Eds.; Routledge: Milton Park, UK; New York, NY, USA, 2019; pp. $40-56$.

46. Roberts, D.A.; Östman, L. (Eds.) Problems of Meaning in Science Curriculum; Teachers College Press: New York, NY, USA, 1998.

47. Sund, P. Discerning the extras in ESD teaching: A democratic issue. In Values and Democracy in Education for Sustainable Development. Contributions from Swedish Research; Öhman, J., Ed.; Liber: Stockholm, Sweden, 2008; pp. 57-74.

48. Sund, L.; Pashby, K. Delinking global issues in northern Europe classrooms. J. Environ. Educ. 2020, 51, 156-170. [CrossRef]

49. Sund, L.; Pashby, K. Taking-up ethical global issues in the classroom. In Sustainable Development Teaching: Ethical and Political Challenges; Van Poeck, K., Östman, L., Öhman, J., Eds.; Routledge: Milton Park, UK; New York, NY, USA, 2019 ; pp. $204-212$.

50. Pashby, K.; Sund, L. Critical GCE in the era of SDG 4.7: Discussing HEADSUP with secondary teachers in England, Finland, and Sweden. In Bloomsbury Handbook for Global Education and Learning; Bourn, D., Ed.; Bloomsbury: London, UK, 2020 ; pp. $314-326$.

51. Lindgren, N.; Öhman, J. A posthuman approach to human-animal relationships: Advocating critical pluralism. Environ. Educ. Res. 2019, 25, 1200-1215. [CrossRef]

52. Pedersen, H. Is 'the posthuman' educable? On the convergence of educational philosophy, animal studies and posthumanist theory. Discourse Stud. Cultural. Politics Educ. 2010, 31, 237-250. [CrossRef]

53. Spannring, R. Animals in environmental education research. Environ. Educ. Res. 2017, 23, 63-74. [CrossRef]

54. Payne, P.G. What next? Post-critical materialisms in environmental education. J. Environ. Educ. 2016, 47, 169-178. [CrossRef]

55. Lundegård, I. Personal authenticity and political subjectivity in student deliberation in environmental and sustainability education. Environ. Educ. Res. 2018, 24, 581-592. [CrossRef]

56. Håkansson, M.; Östman, L. The political dimension in ESE: The construction of a political moment model for analyzing bodily anchored political emotions in teaching and learning of the political dimension. Environ. Educ. Res. 2019, 25, 585-600. [CrossRef]

57. Hicks, D.; Bord, A. Learning about global issues: Why most educators only make things worse. Environ. Educ. Res. 2001, 7, 413-425. [CrossRef] 
58. Ojala, M. Hope in the face of climate change: Associations with environmental engagement and student perceptions of teachers' emotion communication style and future orientation. J. Environ. Educ. 2015, 46, 133-148. [CrossRef]

59. Ojala, M. Känslor, värden och utbildning för en hållbar framtid: Att främja en kritisk känslokompetens i klimatundervisning. Acta Didact. Norge. Tidsskr. Fagdidaktisk Forsk. Utviklingsarb. Nor. 2019, 13, 1-17. [CrossRef]

60. Sund, L.; Öhman, J. On the need to repoliticise environmental and sustainability education: Rethinking the post-political consensus. Environ. Educ. Res. 2014, 20, 639-659. [CrossRef]

61. Tillmanns, T. Learning sustainability as an effect of disruption. Environ. Educ. Res. 2020, 26, 14-26.

62. Öhman, J.; Östman, L. Clarifying the ethical tendency in education for sustainable development practice: A Wittgenstein-inspired approach. Can. J. Environ. Educ. 2008, 13, 57-72.

63. Ojala, M. Hope and climate change: The importance of hope for environmental engagement among young people. Environ. Educ. Res. 2012, 18, 625-642. [CrossRef]

64. Todd, S. Toward an Imperfect Education: Facing Humanity, Rethinking Cosmopolitanism; Paradigm Publishers: Boulder, CO, USA, 2009.

65. Mouffe, C. On the Political; Routledge: London, UK, 2005.

66. Öhman, J.; Kronlid, D.O. A pragmatist perspective on value education. In Sustainable Development Teaching: Ethical and Political Challenges; Van Poeck, K., Östman, L., Öhman, J., Eds.; Routledge: Milton Park, UK; New York, NY, USA, 2019 ; pp. 93-102.

67. Pappas, G.F. John Dewey's Ethics. Democracy as Experience; Indiana University Press: Bloomington, IN, USA, 2008.

68. Östman, L.; Öhman, J. A Transactional Approach to Learning, Mind, Culture, and Activity. Forthcoming. 2010.

69. Wickman, P.-O. Teaching learning progressions: An international perspective. In Handbook of Research on Science Education, Volume II; Lederman, N.G., Abell, S.K., Eds.; Routledge: New York, NY, USA, 2014; pp. 145-163.

70. Östman, L.; Van Poeck, K.; Öhman, J. A transactional theory on sustainability teaching: Teacher moves. In Sustainable Development Teaching: Ethical and Political Challenges; Van Poeck, K., Östman, L., Öhman, J., Eds.; Routledge: Milton Park, UK; New York, NY, USA, 2019; pp. 140-152.

71. Rudsberg, K.; Öhman, J. Pluralism in practice-Experiences from Swedish evaluation, school development and research. Environ. Educ. Res. 2010, 16, 95-111. [CrossRef]

72. Van Poeck, K.; Östman, L. Creating space for "the political" in environmental and sustainability education practice: A political move analysis of educators' actions. Environ. Educ. Res. 2018, 24, 1406-1423. [CrossRef]

73. Dodillet, S.; Lundin, S.; Krüger, J.O. Constructing professionalism in teacher education. Analytical tools from a comparative study. Educ. Inq. 2019, 10, 208-225. [CrossRef]

74. McCulloch, G.; Helsby, G.; Knight, P. The Politics of Professionalism: Teachers and the Curriculum; Continuum: London, UK; New York, NY, USA, 2000.

75. Andreotti, V.; Stein, S.; Sutherland, A.; Pashby, K.; Susa, R.; Amsler, S. Mobilising different conversations about global justice in education: Toward alternative futures in uncertain times. Policy Pract. Dev. Educ. Rev. 2018, 26, 9-41.

76. Andreotti, V. Critical literacy: Theories and practices in development education. Policy Pract. Dev. Educ. Rev. 2014, 19, 12-32.

77. Shephard, K.; Rieckmann, M.; Barth, M. Seeking sustainability competence and capability in the ESD and HESD literature: An international philosophical hermeneutic analysis. Environ. Educ. Res. 2019, 25, 532-547. [CrossRef]

78. Vare, P.; Arro, G.; de Hamer, A.; Del Gobbo, G.; de Vries, G.; Farioli, F.; Kadji-Beltran, G.; Kangur, M.; Mayer, M.; Millican, R.; et al. Devising a competence-based training program for educators of sustainable development: Lessons learned. Sustainability 2019, 11, 1890. [CrossRef] 